\title{
Effects of High Pressure on Softening of Japanese Radish and Decomposition of Pectin during Thermal Process
}

\author{
Takashi OKAZAKI, ${ }^{1}$ Tatsuo YONEDA ${ }^{1}$ and Kanichi SUZUKI ${ }^{2}$ \\ ${ }^{1}$ Hiroshima Prefectural Food Technology Research Center, 12-70, Hijiyamahon-machi, Minami-ku, Hiroshima 732, Japan \\ ${ }^{2}$ Department of Applied Biological Science, Hiroshima University, 1-4-4, Kagamiyama, Higashihiroshima 739-8523, Japan
}

Received September 1, 1997; Accepted May 6, 1998

\begin{abstract}
The softening of Japanese radishes and the decomposition of pectin ( $0.5 \%$ pectin solution in $1 / 10 \mathrm{M}$ phosphate buffer, $\mathrm{pH}$ 6.5) during the thermal process $\left(100^{\circ} \mathrm{C}-110^{\circ} \mathrm{C}\right)$ under atmospheric and high pressures $(100 \mathrm{MPa}-400$ $\mathrm{MPa}$ ) were investigated. High pressure decreased the rates of softening for Japanese radishes and the decomposition of pectin during the thermal process. The activation volumes for the softening of Japanese radishes were 4.3 $\mathrm{cm}^{3} / \mathrm{mol}$ at $100^{\circ} \mathrm{C}$ and $3.1 \mathrm{~cm}^{3} / \mathrm{mol}$ at $110^{\circ} \mathrm{C}$, and those for the decomposition of pectin were $10.4 \mathrm{~cm}^{3} / \mathrm{mol}^{\circ}\left(100^{\circ} \mathrm{C}\right)$ and $8.1 \mathrm{~cm}^{3} / \mathrm{mol}\left(110^{\circ} \mathrm{C}\right)$. Though the values indicated that the pressure lowered the pectin decomposition more than the softening of the radish, the ratios of the activation volume at $110^{\circ} \mathrm{C}$ to that at $100^{\circ} \mathrm{C}$ for both phenomena were nearly the same. These results suggested that the resistance to softening of the radish by pressure is closely related to the inhibition of the pectin decomposition in the radish by pressure.
\end{abstract}

Keywords: high pressure, thermal process, Japanese radish, $\beta$-elimination of pectin

In the thermal processing of food, developing a good texture and taste is one of the most important objectives as well as the sterilization of bacteria spores, though processing at a high temperature deteriorates some useful properties of the food. Thus, it is important to develop a new technology that reduces the deterioration of the functional properties of food. For this purpose, we have investigated the effects of the thermal processes combined with high pressure treatment.

Many studies on the utilization of high pressure for food processing have been reported over the past ten years. It was indicated that the pressure-induced egg gels had useful functions superior to the heat-induced egg gels (Hayashi et al. 1989), and also that the appearance, odor, taste and texture of many kinds of foods changed by pressurizing at $500 \mathrm{MPa}$ and at room temperature (Shimada et al., 1990). Some of these phenomena due to pressure are useful for new food processing techniques, and a new type food product like a pressure-processed jam was in fact produced (Horie et al, 1991). On the other hand, the combined effects of temperature and pressure on food components have also been investigated. For example, green tea infusion at $700 \mathrm{MPa}+80^{\circ} \mathrm{C}$ retained most of the tea components such as catechines, vitamin $\mathrm{C}$, and amino acids (Kinugawa et al, 1992). The effect of high pressure on the maillard reaction in the moderate temperature range between $40^{\circ} \mathrm{C}$ and $60^{\circ} \mathrm{C}$ was reported to significantly weaken the browning reactions (Tamaoka et al., 1991). Although there are some investigations on the effects of high pressure at the moderate temperatures from $40^{\circ} \mathrm{C}$ to $80^{\circ} \mathrm{C}$ on the food components, very few reports on the pressure effects at temperatures higher than $80^{\circ} \mathrm{C}$ have been done.

The object of this study is to clarify the influence of high pressure during the thermal process at temperatures equal or higher than $100^{\circ} \mathrm{C}$ on food components. The Japanese radish, a common root vegetable in Japan, was used as the sample.
The Japanese radish is easily oversoftened during thermal processing, and this softening phenomenon is closely related to the decomposition (called trans-elimination) of pectin substances in it (Fuchigami, 1987a). Therefore, the influence of high pressure on the pectin decomposition under the same thermal conditions for the Japanese radish was investigated in order to examine the softening phenomenon of the radish as related to the decomposition behavior of pectin.

\section{Materials and Methods}

Japanese radishes Japanese radish root (av. weight: $1000 \mathrm{~g}$, av. length: $370 \mathrm{~mm}$ ) was used as the sample. The middle part of the radish was cut to $30 \mathrm{~mm}$ in width and it was hollowed out with a cork borer into a cylindrical shape ( $7 \mathrm{~mm}$ diameter) in the direction of the tissue axis. This sample (O.D:7 mm, L:30 mm) was placed in a pressure vessel with water.

Citrus pectin A pectin derived from citrus (Kanto Cemical Co., Inc., Tokyo), which is almost as high in methoxylpectin as that contained in Japanese radishes, was used for the measurements with purification as follows. One percent $(\mathrm{w} / \mathrm{v})$ pectin powder was dissolved in distilled water, and then ethyl alcohol was gradually added to the pectin solution until reaching $70 \%(\mathrm{v} / \mathrm{v})$. After the pectin precipitate appeared in the solution, it was collected by centrifugation $(1400 \times g)$. The precipitate was washed successively with a higher concentration of alcohol and finally with $100 \%$ ethanol and diethyl ether. After the precipitate was dried at room temperature, it was used as the purified pectin. This purified pectin was redissolved in $\mathrm{M} / 10$ phosphate buffer $(\mathrm{pH} 6.5)$ so that the pectin concentration become $0.5 \%(\mathrm{w} / \mathrm{v})$ immediately before the experiment. Two milliliter of the pectin solution was poured into a sample container $(4 \times$ 100 -mm silicone rubber tube sealed at one end) without air 
bubbles, and the open end of the container was sealed up with a silicon rubber plug.

Pressurizing apparatus The apparatus used has been described elsewhere (Okazaki et al., 1996).

Pressurizing procedure The Japanese radish samples or the sample container filled with the pectin solution was inserted into the pressure vessel. After the required pressure was applied to the sample, the pressure vessel was placed for $5 \mathrm{~min}$ in a water bath $\left(25^{\circ} \mathrm{C}\right)$ to make sure that the initial temperature of each sample was the same. After this procedure, the pressure vessel was kept in an oil bath at $100^{\circ} \mathrm{C}$ or at $110^{\circ} \mathrm{C}\left( \pm 0.2^{\circ} \mathrm{C}\right)$ from 5 to $60 \mathrm{~min}$. The pressure vessel was then transferred to the water bath again for $5 \mathrm{~min}$ to cool the sample. The sample was taken out of the pressure vessel after bringing it to atmospheric pressure. During the initial period of heating, the pressure increased to $20-30 \mathrm{MPa}$ due to the thermal expansion of the water in the vessel. Therefore, the pressure was adjusted by controlling the valve.

Hardness of Japanese radish The treated Japanese radish samples were cut to a $5 \mathrm{~mm}$ length and the hardness (N) was measured using a tensipresser (TTP-50BXII, Takemoto Co., Ltd., Tokyo) under the following conditions. The plunger (plane shape, $20 \mathrm{~mm} \phi$ ) speed was $120 \mathrm{~mm} / \mathrm{min}$, and the highest force recorded was measured as the hardness of the sample. The average hardness was calculated from four measurements.

Degree of softening The degree of softening (DS) of the Japanese radish was defined as the ratio of the hardness of the material treated with or without pressure to that of raw material. Thus, the DS value indicates that the material became hard when the value was larger than unity, and became soft when it was lower than unity.

Measurement of trans-elimination of pectin When

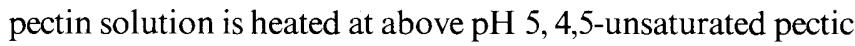
acid is produced by trans-elimination ( $\beta$-elimination) (Albersheim et al, 1960). The 4,5-unsaturated pectic acid reacts with thiobarbituric acid, and the products indicate a peak absorbance at $548 \mathrm{~nm}$. The reaction was carried out according to the following method (Okamoto et al., 1964). After $0.5 \mathrm{ml}$ of sodium periodate $\left(0.025 \mathrm{~N}\right.$ in $\left.0.125 \mathrm{~N} \mathrm{H}_{2} \mathrm{SO}_{4}\right)$ was added to

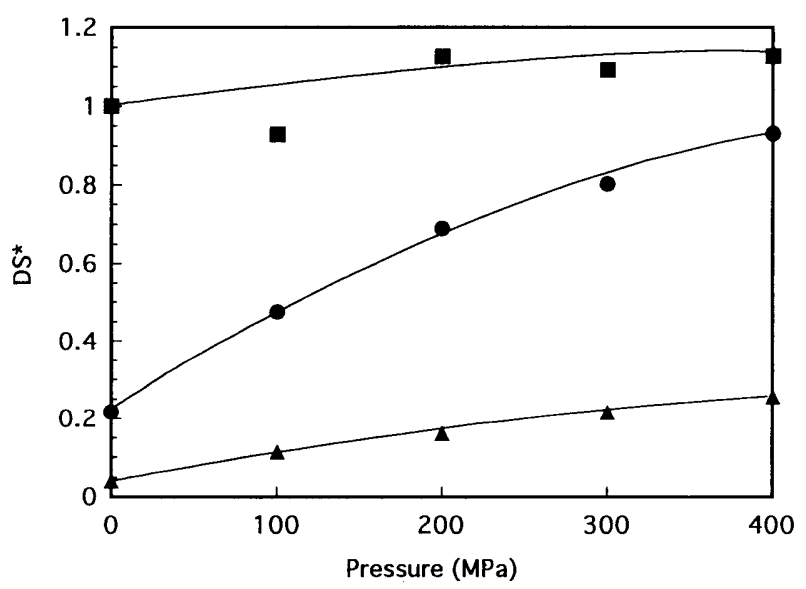

Fig. 1. Effect of high pressure on softening of Japanese radish during thermal process ( $\mathbf{\square}: 25^{\circ} \mathrm{C}, \boldsymbol{\bullet}: 100^{\circ} \mathrm{C}, \boldsymbol{\Delta}: 110^{\circ} \mathrm{C}$ ) for $15 \mathrm{~min} .{ }^{*} \mathrm{DS}$; degree of softening (DS=hardness of treated material/that of raw material)
$0.4 \mathrm{ml}$ of the pressurized pectin solution in a glass tube with a cup, the pectin solution was heated at $80^{\circ} \mathrm{C}$ for $15 \mathrm{~min}$. One milliliter of sodium arsenite $(2 \%$ in $0.5 \mathrm{~N} \mathrm{HCl})$ was then added to the pectin solution. After waiting for $2 \mathrm{~min}, 4 \mathrm{ml}$ of thiobarbituric acid $(0.3 \%)$ was added to the pectin solution, and the solution was heated at $100^{\circ} \mathrm{C}$ for $10 \mathrm{~min}$. The absorbance of the solution was measured at $548 \mathrm{~nm}$ after it was cooled to room temperature. In this study, the progress of the $\beta$-elimination was directly indicated by the change in the absorbance at $548 \mathrm{~nm}$.

\section{Results and Discussion}

The hardness of most of the raw Japanese radishes measured in this study was ca. $50 \mathrm{~N}$, and those of the radishes softened at $100^{\circ} \mathrm{C}$ for $15 \mathrm{~min}$ were ca. $10 \mathrm{~N}$. This meant that the DS value was 0.2 , and the softened radish was appropriate for eating according to the organoleptic test in our laboratory. Thus, a DS value lower than 0.2 indicates that the radish is in the an "overcooked" state.

The effect of high pressure on the softening of Japanese radishes during the thermal processings at $100^{\circ} \mathrm{C}$ and $110^{\circ} \mathrm{C}$ for $15 \mathrm{~min}$ is shown in Fig. 1. Under atmospheric pressure, the DS values reached 0.2 or lower. However, under pressurized conditions, the DSs rose with the increase in pressure from the values heated at atmospheric pressure even under the same thermal conditions. Note that the DS values were about 0.8 or higher when the radishes were heated at $100^{\circ} \mathrm{C}$ at the pressures higher than $300 \mathrm{MPa}$. The Japanese radishes in these cases retained almost raw hardness. The tissue of the radish heated at $110^{\circ} \mathrm{C}$ for $15 \mathrm{~min}$ under atmospheric pressure was almost destroyed. However, the tissue was not destroyed when the radish was heated at pressures higher than $300 \mathrm{MPa}$. From these results, it is obvious that high pressure inhibited the softening of the Japanese radishes during the thermal process.

The high pressure also influenced the hardness of the Japanese radish treated without heating treatment. The DS values of the radish pressurized at $25^{\circ} \mathrm{C}$ under pressures higher than $200 \mathrm{MPa}$ were about 1.1 or higher. This means that the Japanese radish became hard by only applying high pressure. Kasai et al. (1995) have previously shown the same phenome-

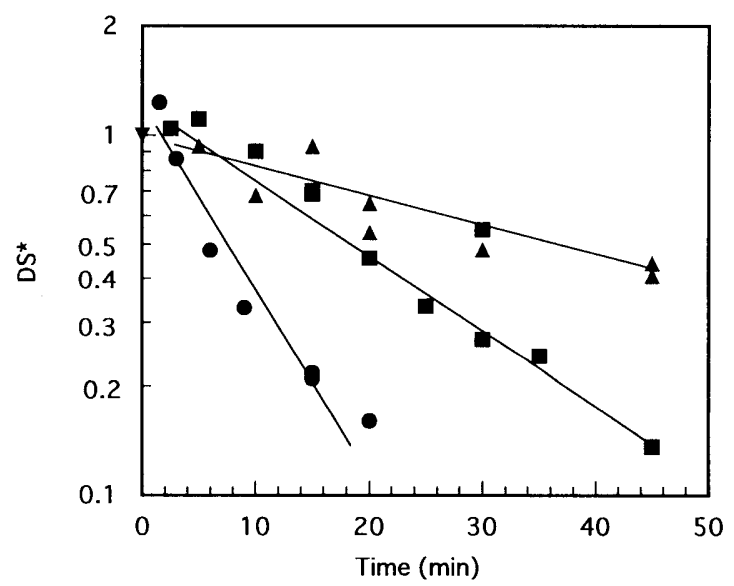

Fig. 2. Changes in hardness of Japanese radish during thermal processes at $100^{\circ} \mathrm{C}$ under high pressure ( $\boldsymbol{\nabla}$ : untreated, $\bullet: 0.1 \mathrm{MPa}, \mathbf{\square}: 200 \mathrm{MPa}, \mathbf{\Delta}: 400$ $\mathrm{MPa}){ }^{*} \mathrm{DS}$ is the same as that of Fig. 1. 
non, and discussed the effect of high pressure on the activities of some enzymes which -affect pectic substances in the tissue.

The influence of time on the DS value of the Japanese radish heated at $100^{\circ} \mathrm{C}$ under atmospheric pressure, $200 \mathrm{MPa}$ and $400 \mathrm{MPa}$ is shown in Fig. 2. At atmospheric pressure, the DS value reached 0.2 during heating for only $15 \mathrm{~min}$. However, it took about $36 \mathrm{~min}$ to reach the same DS value at $200 \mathrm{MPa}$, and the radish did not soften to the DS value required to eat the radish even when the sample was treated for more than $50 \mathrm{~min}$ at $400 \mathrm{MPa}$. These results showed that the high pressure significantly delayed the softening rate, and the effects of higher pressure were greater.

The results shown in Fig. 2 indicated that the softening of the Japanese radish during the thermal process at high pressure could be analyzed by a first order kinetic model as well as that during the thermal process at atmospheric pressure (Okazaki et al, 1997). The softening rate constant and the regression coefficient at each pressure level evaluated by the linear regression are shown in Table 1 (the data at 100 $\mathrm{MPa}$ and $300 \mathrm{MPa}$, and those at $110^{\circ} \mathrm{C}$ are not shown in Fig. 2). The obtained regression coefficients were higher than 0.9 except for the results at $300 \mathrm{MPa}$ and $400 \mathrm{MPa}$ at $100^{\circ} \mathrm{C}$ and $400 \mathrm{MPa}$ at $110^{\circ} \mathrm{C}$.

Fuchigami (1987b) has already studied the relationship between the maceration of vegetables and $\beta$-elimination of pectins in vegetables during cooking. If the softening of a vegetable is closely related to the $\beta$-elimination of pectin, the high pressure might influence the $\beta$-elimination rate of pectin during the thermal process. The effects of high pressure on the $\beta$-elimination of the citrus pectin, which is almost as high in methoxylpectin as that contained in Japanese radish, are shown in Fig. 3, where the experimental conditions were the same as those shown in Fig. 1. The high pressure significantly inhibited the $\beta$-elimination of the pectin. The higher pressure delayed the $\beta$-elimination more effectively at both $100^{\circ} \mathrm{C}$ and $110^{\circ} \mathrm{C}$. Furthermore, the effect of the pressure on the $\beta$-elimination as shown in Fig. 3 indicated nearly the same tendency as the effect of the softening of the Japanese radish shown in Fig. 1.

The progress of $\beta$-elimination of pectin at $100^{\circ} \mathrm{C}$ under normal and high pressures $(200 \mathrm{MPa}$ and $400 \mathrm{MPa})$ are shown in Fig. 4 . The $\beta$-elimination rapidly progressed at atmospheric pressure compared with that at high pressures. The high pressure significantly inhibited the progresses of $\beta$-elimination. At $400 \mathrm{MPa}$, the $\beta$-elimination changed only one-third of the equilibrium value for atmospheric pressure,

Table 1. Kinetic parameters for softening of Japanese radish by thermal process under high pressure.

\begin{tabular}{cccccc}
\hline $\begin{array}{c}\text { Temp. } \\
(\mathrm{K})\end{array}$ & $\begin{array}{c}\text { Pressure } \\
(\mathrm{MPa})\end{array}$ & $\begin{array}{c}\text { Rate constant } \\
\left(\times 10^{-3} \mathrm{~s}^{-1}\right)\end{array}$ & $\mathrm{r}^{2}$ & $\begin{array}{c}\text { Apparent activation } \\
\text { volume }(\mathrm{ml} / \mathrm{mol})\end{array}$ & $\mathrm{r}^{2}$ \\
\hline 373.2 & 0.1 & 0.577 & 0.946 & $4.25 \pm 0.59$ & 0.946 \\
& 100 & 0.365 & 0.949 & & \\
& 200 & 0.339 & 0.916 & & \\
& 300 & 0.186 & 0.715 & & 0.969 \\
& 400 & 0.167 & 0.813 & & \\
\hline 383.2 & 0.1 & 1.817 & 0.953 & $3.13 \pm 0.56$ & \\
& 200 & 1.005 & 0.917 & & \\
& 400 & 0.735 & 0.960 & & \\
\hline
\end{tabular}

even after the pectin solution was treated for $180 \mathrm{~min}$. The relationship between the progress of $\beta$-elimination and pressure at $110^{\circ} \mathrm{C}$ (figure not shown) was almost the same as that at $100^{\circ} \mathrm{C}$ shown in Fig. 4.

The kinetic study of the $\beta$-elimination of pectin during the thermal process at atmospheric pressure was discussed in a previous paper (Okazaki et al., 1997), in which the decomposition ratio of pectin $\left(X_{\mathrm{p}}\right)$ is defined by the following equation;

$$
X_{\mathrm{p}}=\left(A-A_{0}\right) /\left(A_{\mathrm{e}}-A_{0}\right)
$$

where $A$ is the absorbance (at $548 \mathrm{~nm}$ ) of the treated pectin solution, $A_{0}$ is the initial absorbance of the pectin solution (0.02) and $A_{\mathrm{e}}$ is the equilibrium value of $\beta$-elimination $(0.243)$ that was determined as the absorbance of pectin solution heated at $110^{\circ} \mathrm{C}$ for $8 \mathrm{~h}$. If the $\beta$-elimination process obeys a first order kinetic model, the next equations are available;

$$
\begin{gathered}
\mathrm{d} X_{\mathrm{p}} / \mathrm{d} t=k_{\mathrm{p}}\left(1-X_{\mathrm{p}}\right) \\
\ln \left(1-X_{\mathrm{p}}\right)=-k_{\mathrm{p}} \cdot t
\end{gathered}
$$

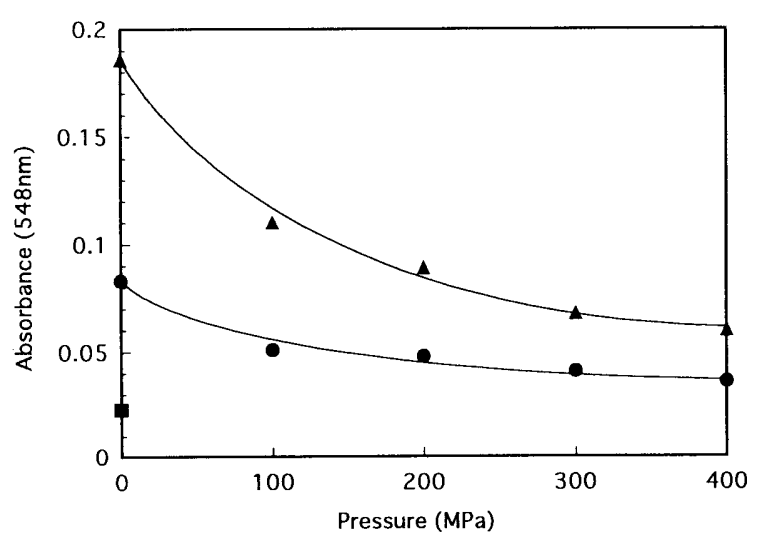

Fig. 3. Effect of high pressure on $\beta$-elimination of citrus pectin during thermal processes $\left(\mathbb{\square}: 25^{\circ} \mathrm{C}, 100^{\circ} \mathrm{C}, \Delta: 110^{\circ} \mathrm{C}\right)$ for $15 \mathrm{~min}$. Pectin solution is $0.5 \%(\mathrm{w} / \mathrm{v})$ with $1 / 10 \mathrm{M}$ phosphate buffer $(\mathrm{pH} 6.5)$.

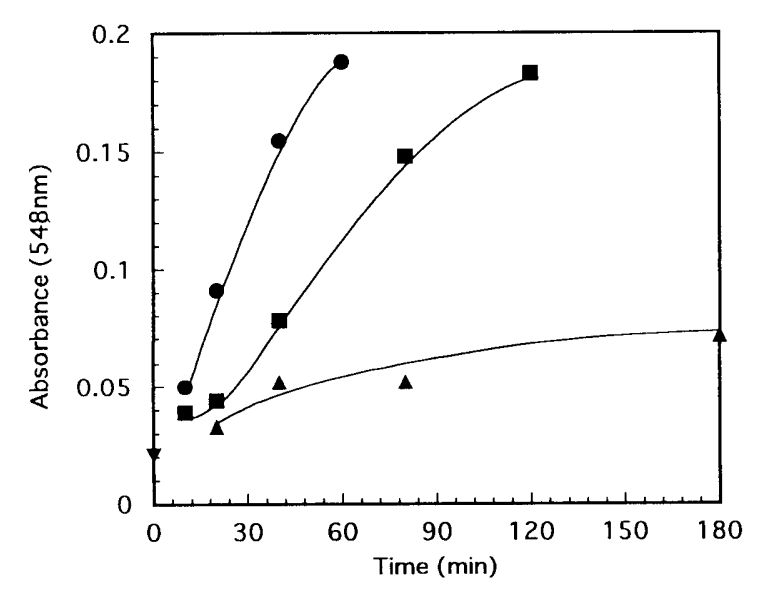

Fig. 4. Progress in $\beta$-elimination of pectin at $100^{\circ} \mathrm{C}$ under high pressure $(\boldsymbol{\nabla}$ untreament, $0.1 \mathrm{MPa}, \mathbf{\square}: 200 \mathrm{MPa}, \mathbf{\Delta}: 400 \mathrm{Ma}$ ). 
Table 2. Kinetic parameters for decomposition of pectin by thermal process under high pressure.

\begin{tabular}{cccccc}
\hline $\begin{array}{c}\text { Temp. } \\
(\mathrm{K})\end{array}$ & $\begin{array}{c}\text { Pressure } \\
(\mathrm{MPa})\end{array}$ & $\begin{array}{c}\text { Rate constant } \\
\left(\times 10^{-4} \mathrm{~s}^{-1}\right)\end{array}$ & $\mathrm{r}^{2}$ & $\begin{array}{c}\text { Apparent activation } \\
\text { volume }(\mathrm{ml} / \mathrm{mol})\end{array}$ & $\mathrm{r}^{2}$ \\
\hline 373.2 & 0.1 & 1.467 & 0.995 & $10.35 \pm 1.70$ & 0.925 \\
& 100 & 0.922 & 0.998 & & \\
& 200 & 0.690 & 0.990 & & \\
& 300 & 0.131 & 0.930 & & 0.986 \\
& 400 & 0.084 & 0.855 & & \\
383.2 & 0.1 & 3.290 & 0.991 & $8.14 \pm 0.69$ & \\
& 100 & 1.795 & 0.983 & & \\
& 200 & 1.182 & 0.991 & & \\
& 300 & 0.533 & 0.955 & & \\
& 400 & 0.531 & 0.969 & & \\
\hline
\end{tabular}

where $k_{\mathrm{p}}$ is the decomposition rate constant $(1 / \mathrm{s})$ and $t$ is the time (s).

From the relationship between $\left(1-X_{\mathrm{p}}\right)$ and the treatment time, the decomposition rate constant at each pressure is determined by the linear regression. The decomposition rate constants and the regression coefficients are presented in Table 2 . The regression coefficients of the rate constants were obtained in the range from 0.93 to 0.99 except for the case at $100^{\circ} \mathrm{C}+400 \mathrm{MPa}$. This result indicates that the decomposition of pectin by $\beta$-elimination could be represented by a first order kinetic model even at high pressures.

By plotting the logarithmic values of the softening rate constants or the decomposition rate constants as a function of pressure at a constant temperature, activation volumes $(\Delta V$, $\mathrm{cm}^{3} / \mathrm{mol}$ ) could be calculated from the slopes of the linear regression curves, $\Delta V /(R T)$, where $R$ is a gas constant (8.314 $\mathrm{cm}^{3} \cdot \mathrm{MPa} /(\mathrm{K} \cdot$ mole $\left.)\right)$ and $T$ is the absolute temperature $(\mathrm{K})$. The activation volumes for the softening of Japanese radish were $4.3 \mathrm{~cm}^{3} / \mathrm{mol}$ at $100^{\circ} \mathrm{C}$ and $3.1 \mathrm{~cm}^{3} / \mathrm{mol}$ at $110^{\circ} \mathrm{C}$ (Table 1 ), and those for the decomposition of pectin were $10.4 \mathrm{~cm}^{3}$ / $\mathrm{mol}$ at $100^{\circ} \mathrm{C}$ and $8.1 \mathrm{~cm}^{3} / \mathrm{mol}$ at $110^{\circ} \mathrm{C}$ (Table 2). Although both values are positive, the latter values were approximately twice as large as the former ones. These results indicated that the pressure lowered the pectin decomposition more than the softening of the radish. Also, nearly the same ratios for the activation volume at $110^{\circ} \mathrm{C}$ as that at $100^{\circ} \mathrm{C}$ for both phenomena ( 1.4 for the softening of Japanese radish and 1.3 for the decomposition of pectin) suggest that the problem of radish softening by pressure is closely related to the inhibition of the decomposition of pectin in the radish by pressure.

In general, when bond cleavage in a chemical raction is suppressed by pressure, the activation volume has a positive value (Asano \& Noble, 1978). The activation volumes evaluated in this study were also positive values, and this indicates that the softening of the Japanese radish is related to bond cleavages or decomposition of some components such as pectin (Okazaki et al., 1997), which is suppressed by pressure. The result that the activation volumes for softening of the Japanese radish are approximately half those for the decomposition of pectin suggests that the softening of the Japanese radish during the thermal process under high pressure may not solely caused by decomposition of pectin by $\beta$-elimination. Other physico-chemical changes and/or enzymatic reactions except for $\beta$-elimination in vivo may also possibly affect the softening of the Japanese radish during the thermal process. Although both activation volumes for the softening and the decomposition became smaller at higher temperature, the limits of this study preclude time for further discussion on this interesting phenomenon.

The hardness or tenderness of food is one of the key elements in its deliciousness. Usually, plant substances exposed to a thermal process for a long time are often too soft For instance, root vegetables such as Japanese radish and carrot, fruits such as apples, cherries and peaches are easily over-softened by heating, and therefore, it is relatively difficult to use these substances on food products processed by heating at temperatures higher than $100^{\circ} \mathrm{C}$. However, if the thermal process is combined with high pressure, the over-softening of such food substances may be avoided, since the softening of vegetables and fruits during heating depends on the decomposition of pectic substances by $\beta$-elimination, as shown in this Japanese radish study.

\section{References}

Albersheim, P., Neukom, H. and Deuel, H. (1960). Splitting of pectin chain molecules in neutral solutions. Arch. Biochem. Biophys., 90 , 46-51.

Asano, T., and Noble, W.J. (1978). Activation and reaction volumes in solution. Chem., Rev., 78, 407-485.

Fuchigami, M. (1987a). Relationship between pectic compositions and the softening of the texture of Japanese radish roots during cooking. J. Food Sci., 52, 1317-1320.

Fuchigami, M. (1987b). Relationship between maceration and pectic substances of vegetable tissues during cooking. Nippon Kasei Gakkaishi, 38, 465-473 (in Japanese).

Hayashi, R., Kawamura, Y., Nakasa, T. and Okinaka, O. (1989). Application of high pressure to food processing: Pressurization of egg white and yolk, and properties of gels formed. Agric. Biol. Chem., 53, 2935-2939.

Horie, Y., Kimura, K., Ida, M., Yoshida, Y. and Ohki, K. (1991). Jam preparation by pressurization. Nippon Nogeikagaku Kaishi, 65 975-980 (in Japanese).

Kasai, M., Hatae, K., Shimada, A. and Iibuchi, S. (1995). Pressure pretreatment of vegetables for controlling the hardness before cooking. J. Jpn. Soc. Food Sci. Technol. 42, 594-601.

Kinugawa, H., Takeo, T., Fukumoto, K. and Ishihara, M. (1992). Changes in tea components during processing and preservation of tea extract by hydrostatic pressure sterilization. Nippon Nogeikagaku Kaishi, 66, 707-712 (in Japanese)

Okamoto, M., Kawamura, Y. and Hayashi, R. (1990). Application of high pressure to food processing: Textural comparison of pressureand heat-induced gels of food proteins. Agric. Biol. Chem., 54, 183189.

Okamoto, K., Hatanaka, T. and Ozawa, T. (1964). Reaction of thiobarbituric acid with 4,5-unsaturated digalacturonic acid Nougaku Kenkyuu, 50, 61-65 (in Japanese).

Okazaki, T., Kakugawa, K., Yoneda, T. and Suzuki, K. (1996). Combined effects of temperature and pressure on inactivation of heat-resistant bacteria. High Pressure Bioscience and Biotechnology, Kyoto, Japan, pp. 415-418

Okazaki, T., Maeshige, S. and Suzuki, K. (1997). Kinetic studies on softening of Japanese radish and $\beta$-elimination of citrus pectin during thermal process. Nippon Shokuhin Kagaku Kogaku Kaishi, 44, 647-652 (in Japanese).

Shimada, A., Kasai, M., Yamamoto, A. and Hatae, K. (1990). Changes in the palatability of foods by hydrostatic pressurizing. Nippon Shokuhin Kogyo Gakkaishi, 37, 511-519 (in Japanese).

Tamaoka, T., Itoh, N. and Hayashi, R. (1991). High pressure effect on maillard reaction. Agric. Biol. Chem., 55, 2071-2074. 